\title{
Milloin naisten koulutus ja kyvyt täyskäyttöön?
}

\section{Miehet ja naiset aikuiskoulutuksessa. Tilastokeskus Aikuiskoulutustutkimus 1990. Koulu- tus 1995:1. Irja Blomqvist.}

Olen lukenut tutkimusta viime viikkoina ja yrittänyt miettiä, miten sen luvut heijastavat todellisuutta ympärilläni. Naiset hävisivät eduskuntavaalit. Kevään palkkaneuvottelu-kierroksella vientiliitot pärjäsivät, naisvaltaiset alat eivät. Palkkaerot kasvavat edelleen. Hallitusohjelmasta ei voi vielä sanoa mitään, mutta en ole huomannut hurmioitunutta paatosta tasa-arvosta puhuttaessa.

Mitä tekemistä näillä pohdinnoilla ja tällä tutkimuksella on keskenään? Kaikki. Koulutusihmisenä olen aina uskonut, että koulutuksella tasa-arvo lisääntyy ja toteutuu. Ei ehkä yhdessä sukupolvessa, mutta joskus. Olen uskonut, että koulutus on tie eteenpäin; myös naisille. Tätä tutkimusta lukiessa usko alkaa hiipua. Jos naiset kouluttavat itseään enemmän kuin miehet, niiksi se ei sitten näy missään? Jos koulutus on naisten päästrategia tiellä tasa-arvoiseen maailmaan ja työelämään, kuinka paljon enemmän koulutettuja naisten pitää olla kuin miesten? Kuinka paljon enemmän koulutettuja kuin tällä hetkellä? Mitä koulutusta naisten tulisi hankkia itselleen? Onko niin, että koulutus viekin tasa-arvoa aivan väärään suuntaan? Jos strategiaksi ei käy barrikaadilinja tai toisaalta asialinjalla pysyvä työnteko ja itsensä kehittäminen, mitä vaihtoehtoja tasa-arvon edistämisessä jää jäljelle?

Tutkimus antaa tilastomaisen ankaran kuvan koulutuksesta ja tasa-arvosta. Tiedot kerättiin haastattelemalla noin 4000 suomalaista keväällä 1990. Tutkimus on osa laajaa tutkimushanketta, jossa selvitettiin aikuiskoulutukseen osallistumista, koulutustarvetta ja -halukkuutta sekä koulutukseen osallistumisen esteitä ja edellytyksiä.

Tässä korutonta kertomaa tutkimuksen tuloksista. Alle 50-vuotiaat naiset ovat miehiä koulutetumpia. Naisten yleissivistävän koulutuksen taso on korkeampi kuin miesten. Kahtiajako syvenee. Miesvaltaiset koulutusalat ovat tulleet entistä miesvaltaisemmiksi ja naisvaltaiset naisvaltaisemmiksi. Tytöt suorittavat ylioppilastutkintonsa paremmin arvosanoin kuin pojat. Naiset suorittavat tällä hetkellä korkeakoulututkintoja miehiä useammin. Miesten urakehitys on nopeampaa ja yltää pitemmälle kuin naisten. Edes miehiä parempi keskimääräinen koulutustaso ei riitä tuomaan naisille samanveroisia ammatillisia mahdollisuuksia.

Naisten työllisyystilanne on viime aikoina heikentynyt suhteellisesti enemmän kuin miesten. Samanarvoisista töistä maksetaan naisille ja miehille eri palkkaa. Suurin osa noin $70 \%$ yleissivistävään tai harrastetavoitteiseen aikuiskoulutukseen osallistuvista on naisia. Ammattiin tai työhön liittyvään aikuiskoulutukseen naiset osallistuvat enemmän kuin miehet. Naiset osallistuvat henkilöstökoulutukseen useammin kuin miehet. Työnantaja huolehtii miehet koulutukseen, naiset ovat koulutuksessa useammin omasta aloitteestaan. Omaehtoiseen ammatilliseen koulutukseen osallistuvat ovat pääosin pitkän pohjakoulutuksen saaneita naisia. Työajalla tapahtuva itseopiskelu on yleisempää miehillä kuin naisilla. Naiset ovat tutkimuksen mukaan koulutusmyönteisempiä kuin miehet ja heillä on voimakkaammat opiskeluhalut kuin miehillä.

Loppuyhteenvedossa tutkija toteaa, että naisten kouluttautumisen puolesta ei tarvitse kantaa erityisen suurta huolta. Pikemminkin pitäisi miettiä, miten miesten koulutusmotivaatio ja usko koulutukseen saadaan 
säilytettyä! Tutkijan mukaan kouluttamistavoitteistaan luopuvat ensin miehet, koska miehille koulutuksen käytännön hyöty, uralla eteneminen ja vaativimpiin työtehtäviin pääsy merkitsevät enemmän kuin naisille. "Naisille koulutus sinänsä merkitsee enemmän, se tarjoaa vaihtelua, piristää ja kehittää persoonallisuutta", toteaa tutkija. Näin sisäänrakennettuja tutkimuksenkin mallit käsitellä asiaa ovat. Tutkija on myös huolestunut siitä, tuleeko koulutuksen valikoiva vaikutus lisäämään miesten määrää koulutuksesta syrjäytyvien joukossa.

Itse en ole huolestunut miesten syrjäytymisestä koulutuksessa. Varmasti näillä koulutusluvuilta keinot keksitään. Mieskiintiöt ja plussapisteitä vähemmistösukupuolesta, vientiteollisuus ja markkinavoimat asialle. Tai korkea parlamentaarinen komitea pohtimaan koulutuksen arvojen ja suuntien muuttamista vääristymien korjaamiseksi. Tänä aikana tuntuu tosi kummalliselta vaatia arvokeskustelua koulutukseen. Kun ei tiedetä, niitä pitäisi tehdä, halutaan yleensä arvokeskustelua. Mutta siitähän loppujen lopuksi on kysymys. Minkälaista arvomaailmaa ja koulutusta maailmamme ja yhteiskuntamme haluaa ja tarvitsee? Miksi se ei osaa hyödyntää ja arvostaa nykyistä, modernia ja kehittyvää koulutusjärjestelmää? Miksi koulutuksessa on jotain välttämättä pielessä, jos naiset, osallistujien enemmistö pärjää, arvostaa ja osaa hyödyntää sitä? Kännyköiden markkinat ovat rajoitettuja. Kun maailma on kyllästetty niillä, mitä sitten?

Kiitos tutkimuksesta Tilastokeskus. Se avasi uusia pohdinnan ja toiminnan aiheita. En vielä anna periksi siinä, etteikö koulutuksella edistetä tasaarvoa. Ilmeisesti meidän naisten korvien välissä on tapahduttava suuri räjähdys, jotta saamme koulutuksen hyödyn ja kykymme käyttöön. Itse meidän on se tehtävä.

\section{Eva Palin}

\section{MUUTA AIHEESTA:}

Naumanen, Päivi 1994. Tiedon, taidon ja vallan tiellä. Miesten ja naisten kouluttautuminen ja työ. Koulutussosiologian tutkimuskeskus. Raportteja 22. Turun yliopisto. 276 s. 